УДК 378.1:37.022:340.6(477.84)

\title{
ОСОБЛИВОСТІ ОРГАНІЗАЦІЇ ТА ПРОВЕДЕННЯ НАВЧАННЯ АНГЛОМОВНИХ ІНОЗЕМНИХ СТУДЕНТІВ НА КУРСІ СУДОВОЇ МЕДИЦИНИ ТДМУ ІМЕНІ І. Я. ГОРБАЧЕВСЬКОГО
}

\author{
С. В. Трач Росоловська
}

ДВНЗ “Тернопільський держсавниймедичнийуніверситет імені І. Я. Горбачевського МОЗ Украйни”

\section{PECULIARITIES OF ORGANIZATION AND TRAINING OF ENGLISH- SPEAKING FOREIGN STUDENTS AT THE FORENSIC MEDICINE COURSE OF TSMU BY I. YA. HORBACHEVSKY}

\author{
S. V. Trach Rosolovska \\ SHEI "Ternopil State Medical University by I. Ya. Horbachevsky of MPH of Ukraine"
}

\begin{abstract}
У статті відображено особливості викладання судової медицини англомовним іноземним студентам на кафедрі патологічної анатомії з секційним курсом та судової медицини Тернопільського державного медичного університету імені І. Я. Горбачевського за кредитно-модульною системою навчання. Описані основні методики, які застосовуються в навчальному процесі. Використання цих методик забезпечує більш якісний рівень засвоєння матеріалу іноземними студентами.

The article deals with the peculiarities of teaching of Forensic Medicine for english - speaking foreign students at the Department of Pathomorphology with Sectional Course and Forensic Medicine of Ternopil State Medical University by the credit-modular system. Basic methodologies which are used in the educational process are described. Using of these techniques provides a higher level of material mastering by foreign students.
\end{abstract}

Вступ. Одним з пріоритетних напрямків сучасної національної системи медичної освіти, важливою складовою євроінтеграції, є якісна професійна підготовка іноземних студентів, що посилює позиціїу українських медичних університетів в Свропі та світі, робить їх конкурентоспроможними та, зокрема, суттево підвищує рейтинг того чи іншого навчального закладу на теренах нашої держави $[1,2]$. Нові методики організації навчального процесу, які використовуються в Тернопільському державному медичному університеті імені І. Я. Горбачевського (ТДМУ), наближають наш університет до аналогічних медичних університетів Свропи та Америки [3].

Вдосконалення навчального процесу і підвищення якості підготовки студентів, в тому числі іноземних, $\epsilon$ пріоритетним завданням викладачів кафедри патологічної анатомії з секційним курсом та судової медицини ТДМУ. Проте навчання англомовних іноземних студентів вимагає від викладачів не тільки високого рівня володіння англійською мовою, але й педагогічної майстерності, толерантності, поваги до національних традицій [4]. Англійською мовою на кафедрі викладається ряд дисциплін, кожна 3 яких має свої особливості. Специфіка предмета "Судова медицина" полягає в тому, що необхідність вивчення

\footnotetext{
(C) С. В. Трач Росоловська
}

його у ВМНЗ обумовлена вимогами діючого процесуального законодавства. Судова медицина, як спеціальна медична наука, суттєво відрізняється від інших медичних дисциплін, зокрема : 1) для вирішення питань слідства грунтується на докладному знанні основ медико-біологічних дисциплін: біології, анатомії людини, патологічної анатомії, хірургії, акушерства тощо; 2) з'ясовує ряд специфічних питань, наприклад визначення давності смерті, встановлення ступеня тяжкості тілесних ушкоджень, дослідження речових доказів тощо; 3 ) вивчає танатологію, токсикологію, травматологію та інші розділи медицини в такому обсязі й з такого погляду, які не вивчаються іншими медичними науками; 4) тісно пов'язана 3 юриспруденцією в частині призначення, виконання i оформлення результатів судово-медичних експертиз відповідно до процесуального законодавства [5].

Специфікою викладання предмета для студентів-іноземців $€$ також те, що організаційні засади проведення судово-медичної експертизи мають суттєві відмінності в різних країнах, і викладачу необхідно донести до студента особливості судово-медичної експертної діяльності в Україні і орієнтуватись в особливостях організації судово-медичних служб інших країн.

Теоретичні знання та відповідні практичні навички з дисципліни "Судова медицина" з питань встанов- 
лення факту і давності настання смерті, визначення наявності і характеру тілесних ушкоджень мають неабияке важливе значення, оскільки необхідні кожному лікарю у його майбутній професійній діяльності.

Основна частина. Навчально-методичний процес на курсі судової медицини ТДМУ відповідає всім вимогам діючих державних стандартів освіти з урахуванням стандартів і рекомендацій Болонської декларації. 3 огляду на це, викладачі курсу активно впроваджують нові методики викладання. Організація навчального процесу з викладання профільної дисципліни іноземним англомовним студентам на курсі судової медицини здійснюється за кредитно-модульною системою з 2007 року на медичному факультеті і з 2010 - на стоматологічному. Вивчення судової медицини студентами медичного факультету здійснюється впродовж VII-VIII семестрів 4-го року навчання, студентами стоматологічного факультету - впродовж VI семестру 3-го року навчання. Викладання навчальної дисципліни проходить на базі кафедри патологічної анатомії з секційним курсом та судовою медициною навчально-наукового інституту морфології за методикою “єдиного дня".

Навчальна програма $з$ дисципліни “Судова медицина" для студентів зі спеціальності “Лікувальна справа" структурована на 1 модуль, до складу якого входять 9 змістових модулів, в яких 34 навчальні теми. На вивчення дисципліни відводяться 90 навчальних годин (з них 10 годин - лекційний курс, 48 - аудиторні практичні заняття і 32 години відведено на самостійну позааудиторну роботу студентів). Програма дисципліни для стоматологічного факультету включає 30 годин практичних занять і 8 годин - на самостійну роботу.

На медичному і стоматологічному факультетах викладання судової медицини передбачає вміння встановлення факту настання біологічної смерті, проведення огляду трупа на місці події з описанням та вилученням речових доказів біологічного походження, оволодіння навиками кваліфікованого опису ушкоджень за певною схемою.У 2013/2014 навчальному році в навчальний процес введено матрикул практичних навичок з таких тем, як огляд трупа на місці події і діагностика та описання ушкоджень з встановленням ступеня їх тяжкості.

Викладачами курсу судової медицини підготовлено і розміщено на сайті університету усі необхідні навчальні матеріали англійською мовою (робочі програми, розклади лекцій та практичних занять, презентації лекцій, матеріали підготовки студентів до лекцій та практичних занять, методичні вказівки, банк тестових завдань, навчальні таблиці тощо). Методичні матеріали для іноземних студентів щорічно оновлюються та доповнюються новими науковими даними.

Усі лекції на курсі судової медицини читаються 3 мультимедійним супроводом, що дозволяє суттєво підвищити їх наочність. Використання мультимедійних презентацій під час лекцій дає можливість продемонструвати велику кількість матеріалу у вигляді схем, малюнків, фотографій, а також відеофрагментів, які ілюструють динаміку деяких процесів (техніка судово-медичного розтину трупа, фази наїзду автомобіля на тіло людини тощо). Все це полегшує сприйняття матеріалу, викликає цікавість у студентів і підвищує мотивацію до вивчення предмета.

На практичних заняттях з судової медицини розглядаються питання процесуально-організаційних основ судово-медичної експертизи та медичного законодавства, огляду трупа на місця події, судовомедичної танатології, травматології, судово-медичної експертизи потерпілих, обвинувачених та інших осіб. Також увага надається проблемам правового регулювання трансплантації і донорства в Україні, юридичним аспектам профілактики та лікування ВІЛ/ СНІДу. Деякі практичні заняття з курсу судової медицини для іноземних студентів передбачають інтенсивне засвоєння великого обсягу теоретичного матеріалу, що вимагає від викладачів курсу надання допомоги та індивідуального підходу в його опануванні до кожного студента. Труднощі виникають у студентів-іноземців і з опануванням судово-медичної термінології, особливо серед тих, в кого англійська не є досконалою.

На практичній частині заняття студент у своєму робочому зошиті оформляє "Висновок експерта" згідно з встановленими вимогами, аналізує дані розтину трупа, вивчає медичну документацію і самостійно складає підсумки (дає відповіді на запитання, поставлені слідчим). На семінарському обговоренні викладач перевіряє теоретичну і практичну готовність до заняття, разом із студентами обговорює зміст “висновків” та аналізує відповіді на питання. Запропонована в університеті система оцінки поточної успішності студента за 12-бальною системою залежно від виду діяльності успішно себе зарекомендувала в навчальному процесі на курсі судової медицини, оскільки об'єктивно оцінюється теоретична і практична підготовка студента на занятті і визначається сумарна оцінка за заняття з врахуванням тестового контролю. Щодо підсумкової частини практичного заняття - контролю знань студентів, то англомовні іноземні студенти при вивченні судової медицини надають перевагу не традиційному методу контролю знань (письмові відповіді на тестові запитання), а сучасному 
альтернативному комп’ютерному методу, який передбачений в університеті системою дистанційного оцінювання рівня знань "Moodle".

Діюча в університеті методика “єдиного дня" вимагає належного забезпечення занять навчально-методичною літературою [6]. 3 цією метою для англомовних іноземних студентів доц. В. В. Франчуком був підготовлений навчальний посібник з судової медицини англійською мовою, який поряд із зручним для студента стислим викладом теоретичного матеріалу містить велику кількість кольорових навчальних таблиць, що суттєво полегшує роботу викладача i покращує сприйняття навчального матеріалу студентами [7].

Добре зарекомендував себе запроваджений на курсі з 2012 року цикловий метод навчання, що передбачає вивчення студентами медичного факультету двох окремих циклів впродовж навчального року. В осінньому семестрі - “Загальні питання організації та проведення судово-медичної експертизи та медичне законодавство”, у весняному - циклу “Судово-медична травматологія".

Клінічною базою курсу судової медицини, де створені умови для забезпечення практичного засвоєння навчального матеріалу, $є$ Тернопільське обласне бюро судово-медичної експертизи. Разом з тим, не завжди є можливість продемонструвати студентам під час заняття розтин трупа відповідно до теми, тому коли необхідно пояснити та продемонструвати студентам особливості того чи іншого ушкодження від дії різних предметів (тупих, гострих, вогнепальноїзброї тощо), активно використовується навчальний музей макропрепаратів, заснований з перших днів існування кафедри (курсу) судової медицини, і який налічує близько 1000 експонатів з різноманітних розділів судової медицини. Забезпеченню наочності викладан-

\section{Література}

1.Стан підготовки та підвищення кваліфікації медичних працівників і завдання вищої школи щодо ії інтеграції до світового освітнього простору / В. В. Лазоришинець, М. В. Банчук, О. П. Волосовець [та ін.] // Медична освіта. 2009. - №2. - C. 5-10.

2. Філіпець О. О. Методичні підходи до викладання медичних дисциплін іноземним студентам / О. О. Філіпець, В. М. Пашковський, Н. Д. Філіпець // Медична освіта. 2012. -№3 (додаток). -С. 180-182.

3. Ковальчук Л. Я. Впровадження новітніх методик і систем навчального процесу в Тернопільському державному медичному університеті імені І. Я. Горбачевського / Л. Я. Ковальчук // Медична освіта. -2009. -№2.-С. 10-14. ня судової медицини сприяє і малий судово-медичний музей, який був створений у 2007 році. Його експозиція постійно використовується в навчальному процесі. Фонд музею містить експонати різних видів знарядь і зброї, муляжі ушкоджень, а також два оригінальних макети, що відтворюють місце події. На цих макетах ретельно відтворені усі деталі того місця, де відбувся злочин, з демонстрацією трупа загиблої особи, особливостей ії одягу, ушкоджень та певних слідів і речових доказів.

Особливу увагу викладачі курсу судової медицини звертають на якісну підготовку самостійної роботи іноземних студентів 3 тем, які не увійшли до аудиторних занять та лекцій. На курсі ця робота реалізується студентами шляхом підготовки мультимедійних презентацій на відповідні теми, що дозволяє майбутнім лікарям продемонструвати творчий підхід, проявити ораторські здібності, сприяє зацікавленості в подальшому вивченні дисципліни і виявляє здібних до наукової роботи.

Висновки: 1. Більш ніж десятирічний досвід викладання профільної дисципліни англійською мовою на курсі судової медицини Тернопільського державного медичного університету імені І. Я. Горбачевського свідчить, що запроваджені методики навчання дають можливість отримати англомовним іноземним студентам достатні знання з судової медицини та дозволяють оволодіти відповідними практичними навиками з предмета, необхідними майбутньому лікарю.

2. Колектив курсу судової медицини наполегливо працює, забезпечуючи індивідуальний підхід до кожного іноземного студента, максимально реалізує свої навчально-методичні здобутки, щоб якісно на сучасному рівні організувати навчальний процес і забезпечити високий рівень підготовки іноземних студентів університету.

4. Деякі аспекти підвищення якості навчання англомовних студентів / Г. С. Сенаторова, Н. І. Макєєва, Т. Б. Іщенко [та ін.] // Сучасний стан, проблеми та перспективи англомовного навчання у ХНМУ : матеріали XLV навчальнометодичної конф. - Харків, 2011.-Вип. 2. - С. 140-143.

5. Завальнюк А. Х. Судова медицина : курс лекцій / А. Х. Завальнюк. -2-ге видання, перероблене і доповнене. - Тернопіль : Укрмедкнига, 2006.-672 с.

6. Ковальчук Л. Я. Результати реалізації концепції розвитку Тернопільського державного медичного університету імені І. Я. Горбачевського на шляху його входження у світовий освітній простір / Л. Я. Ковальчук // Медична освіта. 2011. - №2.- C. 12-20.

7. Forensic Medicine: practical guide / V. V. Franchuk. Ternopil, 2011.-2004 p. 